UDC 621.791 .75

DOI: 10.15587/2706-5448.2021.235405

Article type «Original research»

\title{
Vyacheslav Royanov, Irina Zakharova \\ USE OF PULSED SPRAY AIRFLOW FOR ELECTRIC ARC SPRAYING OF DIFFERENT TYPES OF WIRES
}

The object of research is the control of the process of formation of a spraying air flow and the transfer of particles of liquid metal from electrodes during arc spraying. One of the problem areas of the arc spraying process is the oxidation of the sprayed metal particles by the oxygen of the air flow during their transportation to the sprayed surface. This leads to the formation of a sufficiently large amount of oxides of chemical elements, which significantly deteriorate the adhesion strength and burn out alloying elements that are necessary to obtain a wear-resistant and corrosion-resistant coating. The suitability and durability of coatings during use depends on the strength of adhesion to the substrate.

In the course of the study, methods were used to determine the adhesion strength of the coating to the base the Steffens method and methods for studying the microstructure of coatings were taken as the basis. The data was processed and dependencies were plotted.

The proposed method makes it possible to improve the quality of the resulting coating in terms of such an indicator as improvements in chemical composition. And also to influence the chemical composition by controlling the process of transfer of molten metal using a pulsating air flow.

The obtained results of approbation of the method allow us to consider it effective, as evidenced by the quality of the obtained coatings. This is due to the fact that the correctness of the formulation and solution of the problem provided adequate results. In contrast to the existing methods, the proposed one makes it possible to significantly influence the amount of harmful oxygen involved in the formation of a sprayed coating, which makes it possible to obtain a sprayed layer with the required performance characteristics. And also allows to improve its quality without significant capital costs. In addition, the issues of resource and energy saving are being addressed, since the burnout of chemical elements decreases and the air consumption during arc metallization decreases. To solve this problem, a simple design of the pulsator is proposed, which provides the ability to control the spray flow by adjusting the level of overlapping of the holes.

Keywords: pulsating spray flow, sprayed surface, adhesion strength, wear-resistant and corrosion-resistant coating.

Royanov, V., Zakharova, I. (2021). Use of pulsed spray airflow for electric arc spraying of different types of wires. Technology Audit and Production Reserves, 3 (1 (59)), 23-27. doi: http://doi.org/10.15587/2706-5448.2021.235405

\section{Introduction}

Spraying technology is widely used in the restoration and hardening of worn-out parts of equipment in machinebuilding, metallurgical, mining, agricultural industries operating under conditions of abrasive, shock-abrasive and gas-abrasive wear, and to which new and more stringent requirements are constantly applied. Modern requirements for the operational characteristics of the restored surfaces of parts are aimed at reducing the specific technological costs during spraying in combination with invariably high complex indicators of the quality of coatings. In this regard, scientifically based proposals for resource- and energysaving spraying processes are in demand and relevant for various industrial industries. Therefore, research to overcome these listed difficulties in any part of them should be considered relevant.

\section{The object of research and its technological audit}

The object of research is the control of the process of formation of a spraying air flow and the transfer of particles of liquid metal from electrodes during arc spraying.

The process of formation of thermal gas coatings (Fig. 1) consists in fine spraying of the initial material (in the case of its compact state) into small particles, heating the particles to a molten or plastic state and moving them with a gas jet until they collide with the surface of the product [1,2].

The analysis of the existing data on electric arc spraying shows that one of the main disadvantages of the process is the oxidation of the sprayed metal particles by the oxygen of the air stream during transportation to the sprayed surface. This has a significant impact on the performance of the coating. 


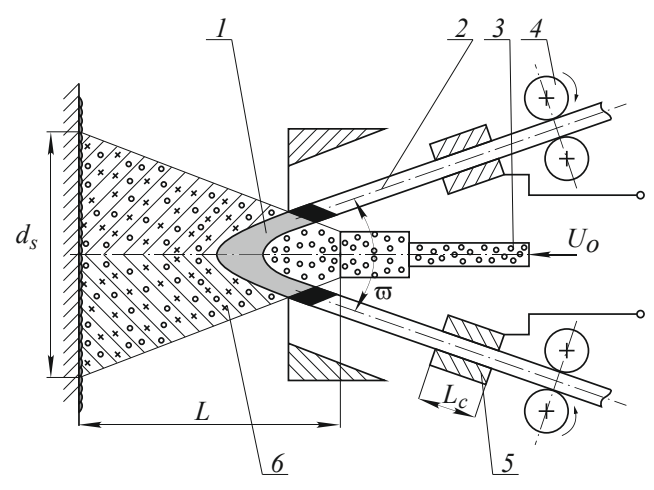

Fig. 1. Schematic diagram of electric arc metallization: 1 - arc burning zone; 2 - sprayed metal electrodes; 3 - nozzle 4 - feed rollers; 5 - current lead; 6 - two-phase flow; $d_{s}$ - diameter of the spraying spot, 120-180 $\mathrm{mm} ; L$ - spraying distance, 100-150 $\mathrm{mm}$;

$L_{c}$ - length of the sliding contact, $10-25 \mathrm{~mm} ; \varpi$ - electrode feed angle, $20-45^{\circ} ; U_{a}$ - air transporting flow

In the practice of electric arc spraying, a number of directions have been adopted to reduce the negative effect of the oxygen of the spraying flow on the quality of the coatings. Conceptually, it is based on the hypothesis of reducing the proportion of oxygen by using gas mixtures of an air flow with carbon-containing and inert gases, or replacing the air flow with other (neutral) gases.

\section{The aim and objectives of research}

The aim of research is to propose a more perfect system for spraying particles during electric arc metallization, using a pulsating spraying air flow for transporting molten particles of electrode wires of various types. This will make it possible to influence the quality of the resulting coatings by reducing the burnout of the elements transferred from the electrodes to the sprayed surface, by reducing the amount of air oxygen involved in the transportation of molten metal.

To achieve the aim, the following objectives have been set:

1. Justify the need to use special low-cost equipment to create a pulsating air flow during arc spraying.

2. Perform a systematic analysis of the data obtained in the process of applying coatings using a pulsed spray flow.

\section{Research of existing solutions to the problem}

Spraying with compressed air provides a stable spray of metal, which melts, but the quality of the coating is not always stable and often does not meet the specified quality requirements due to the abundance of pores and oxides [3]. The use of inert gases for spraying in metallization [4] complicates the technology and equipment and significantly increases the cost of the metallization process.

Among the main directions for solving the problem of improving the quality of coatings, identified in the resources of the world scientific periodicals, a number of publications can be distinguished that consider the promising use of compressed air + carbon containing gas mixtures [5, 6]. This introduces additional heat during the combustion of the mixture, reduces the supply of oxygen to the metal droplets during the reducing nature of the gas jet. With this option, it is proposed, for example, to use methane in a mixture with air. On an industrial scale, kerosene is widely used as hydrocarbons, which is introduced in portions into the transporting air stream; it has also been proposed to use the products of combustion of a propane-oxygen mixture as a transporting gas [7]. However, in these works, quantitative calculations are either absent altogether, or are of an approximate nature, which does not allow to fully realize the advantages of the chosen scheme.

Air Products and Chemical Inc. (USA) proposed to use argon, nitrogen, carbon dioxide, sulfur hexafluoride or their mixture for spraying chemically active metals during metallization [8, 9]. At the same time, a technologically complex option has been proposed, in which the mass flow rates of metal and gas are correlated in a ratio of approximately $1: 10$. In normal modes, the gas consumption for metal is an order of magnitude lower.

Thus, the results of the analysis allow to conclude that all the proposed options for improving the technology of electric arc metallization do not significantly impede the access of oxygen to the arc burning zone. Thus, when argon, nitrogen or their mixture is supplied to the central transporting jet, oxygen is inevitably mixed due to the turbulence of the flow and the incommensurably small ratio of the volume of inert gases to the total volume of the air flow [10, 11]. In the air + hydrocarbons variant, the mixture already contains oxygen. In this case, as well as with inert gases, the cost of coatings increases significantly due to the presence of additional costs [12, 13]. The importance of increasing the efficiency of coatings is confirmed by the constant search for solutions aimed at simplifying the technology and reducing costs [14].

Within the framework of this approach, the authors of the work proposed the use of pulsations of a spraying air flow during electric arc spraying. The pulsations of the spraying flow are achieved by using a pulsator, which is connected to the air supply system of the electric arc metallizer according to the kinematic scheme, Fig. 2.

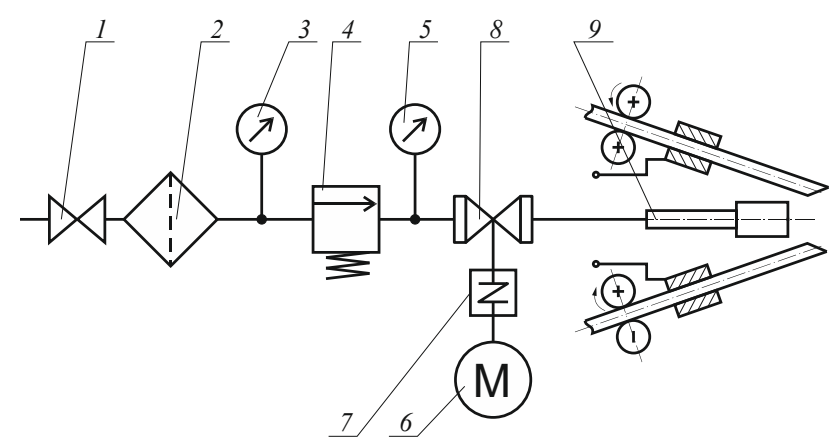

Fig. 2. Kinematic diagram of the installation of electric arc spraying with a pulsating spraying flow: 1 - inlet valve from the main; 2 - moisture separator; 3, 5 - manometer; 4 - pressure reducing valve; 6 - engine; 7 - clutch; 8 - pulsator; 9 - spray nozzle of the metallizer

The pulsation of the atomizing flow is ensured by using a pulsator of a simple design. A rotary valve is used as a prototype [15].

Fig. 3 shows the principle of operation of the pulsator, in which a rod rotating at a given speed, with a through hole, periodically closes the inlet and stops the air flow.

After a complete rotation of the rod, the air flow is resumed, while to get the opportunity, by changing the rotation speed of the rod, to change the frequency of the pulsation of the air flow. 


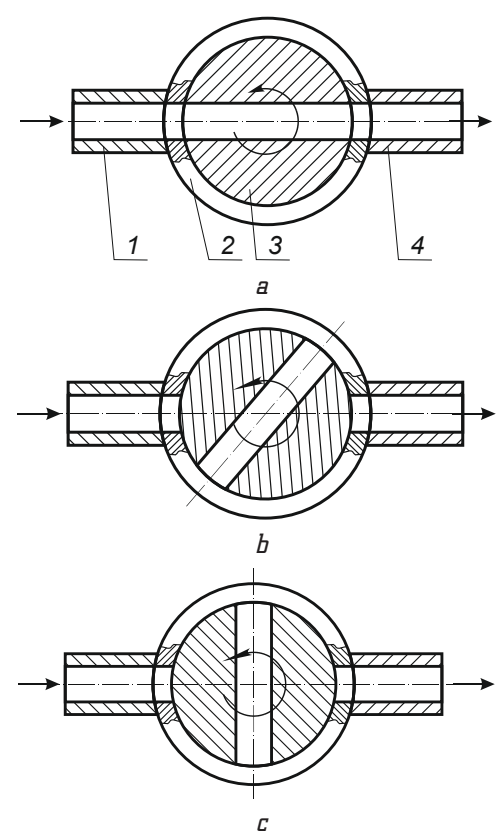

Fig. 3. Scheme of operation of the rotary valve: $a$ - the valve is open; $b$ - the valve is closed, the stem is turned $45^{\circ}$; $c$ - the valve is closed, the stem is turned $49^{\circ} ; 1$ - inlet air branch pipe; 2 - case; 3 - stock; 4 - outlet branch pipe

In $[16,17]$, the influence of a pulsating spraying flow on the quality of coatings obtained by spraying Sv-08A, 12Kh18N10T, 10G2FB seamless wires was considered and the following results were obtained:

- the burnout of such alloying components as carbon, manganese, silicon decreases, their amount in the coating composition increases. The carbon content increases by $0.07 \%$, which in absolute terms corresponds to an increase of $35 \%$, manganese by $0.045 \%$ (36\%), silicon by $0.03 \%$ (38 \%);

- air consumption is reduced by 35-40\% when $1 \mathrm{~kg}$ of sprayed metal is applied, and, as a consequence, electricity consumption for its production, which is an important indicator of the economic efficiency of the arc metallization process;

- a decrease in the mass of oxygen at a pulsation frequency of $120 \mathrm{~Hz}$ by about 40 times, and at a pulsation frequency of $60 \mathrm{~Hz}$ by about 2.5 times;

- increasing the size and level of productivity and efficiency of material use. The maximum increase in the level of spraying performance reaches $\approx 25 \%$ and the efficiency of using the sprayed material $\approx 40 \%$ at a pulsation frequency of the air flow of $70 \mathrm{~Hz}$;

- increasing the adhesion strength of coatings to the base by 1.5 times.

\section{Methods of research}

The authors investigated the possibility of using a pulsating spraying flow in arc spraying of flux-cored wires, which were not previously presented.

For research were selected flux-cored wires, the composition of which is shown in Table 1.

The spraying process was carried out in the modes recommended for flux-cored wires. Spraying was carried out using an EM-17 electric arc metallizer (manufactured by OJSC Barnaul Hardware and Mechanical Plant, RF) with the developed device at the following modes: pressure $P=0.55 \mathrm{MPa}$, current $I=210-230 \mathrm{~A}$, voltage $U=30-32 \mathrm{~V}$, wire feed speed $v=4.8-5.4 \mathrm{~m} / \mathrm{min}$. For spraying, a nozzle with a diameter of $d=7 \cdot 10^{-3} \mathrm{~m}^{2}$ was used. The distance to the sprayed sample is $120 \mathrm{~mm}$. The arc was powered from a VDU-506 source (produced by the Pilot Plant of Welding Materials of the E. O. Paton Electric Welding Institute, Ukraine).

Table 1

Chemical composition of coatings obtained with various flux-cored wires using pulsating air flow

\begin{tabular}{|c|c|c|c|c|}
\hline \multirow{2}{*}{ Flux-cored wire } & \multicolumn{4}{|c|}{ Chemical composition of coatings, \% } \\
\cline { 2 - 5 } & ᄃ, \% & $\mathrm{Mn}, \%$ & ᄃr, \% & $\mathrm{Al}, \%$ \\
\hline PP-MM-2 (0.5 \%) & 0.17 & 0.45 & 2.33 & 3.07 \\
\hline PP-MM-2M (1.0 \%) & 0.32 & 0.48 & 2.55 & 2.26 \\
\hline PP-MM-2M (1.5\%) & 0.23 & 0.54 & 3.66 & 1.89 \\
\hline PP-MM-2M (2 \%) & 0.22 & 0.47 & 1.85 & 1.04 \\
\hline
\end{tabular}

The study of the microstructure and microhardness of the particles of the sprayed coating of the flux-cored wire PP-MM-2 was carried out on an LM-100 device (Ukraine) at a load of $500 \mathrm{~g}$. In order to obtain stable results and reduce the research error, the particles were selected at an equidistant section from the base.

\section{Research results}

Fig. 4 shows the microstructure and microhardness of individual coating particles.

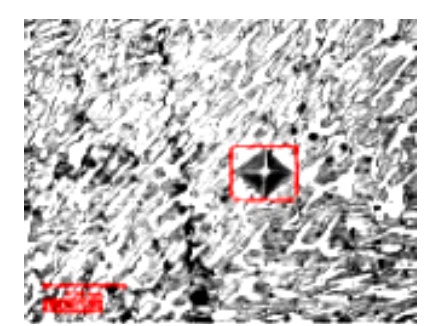

a

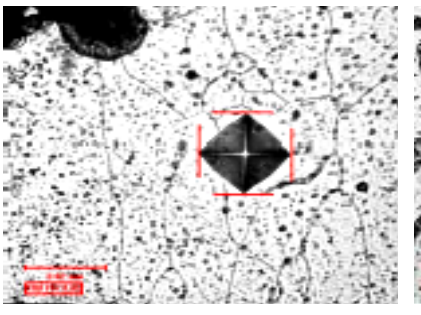

C

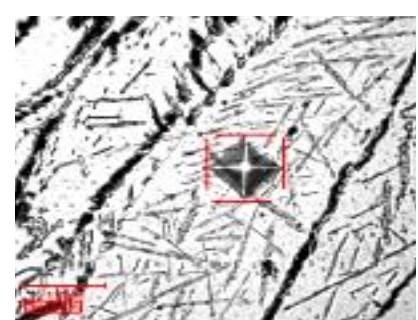

$b$

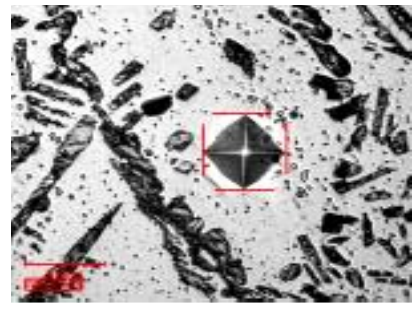

d
Fig. 4. Microstructure and microhardness of individual coating particles at different pulsation frequency, $\times 500$ : $a-$ pulsations $25 \mathrm{~Hz}$, pearlite structure with uniformly distributed chromium carbides, hardness $311 \mathrm{HV}$; $b$ - pulsations $43 \mathrm{~Hz}$, lamellar pearlite structure with uniformly distributed chromium carbides, areas of free aluminum, $276 \mathrm{HV}$; $c$ - pulsations $65 \mathrm{~Hz}$, finely dispersed sorbitol with chromium carbides, hardness $320 \mathrm{HV}$; $d$ - pulsations $105 \mathrm{~Hz}$, lamellar pearlite, ferrite and chromium carbides, $349 \mathrm{HV}$

Analysis of the presented microstructures shows that the characteristic structure of particles is mainly ferrite or ferrite-pearlite with the presence of a carbide phase or inclusions of chromium and aluminum oxides (Fig. 4, $a$ ). 
It should be noted that with increasing frequency, the amount of the carbide phase in the coating particles increases (Fig. 4, b, c). At a frequency of $105 \mathrm{~Hz}$, quenching structures appear in the particles (Fig. 4, c), which is probably due to a change in the particle size and an increase in cooling rates. At the same time, the ferritepearlite structure with the inclusion of carbides prevails in the coating particles at a frequency of $105 \mathrm{~Hz}$.

Studies of the adhesion strength for the used fluxcored wires were carried out, Fig. 5.

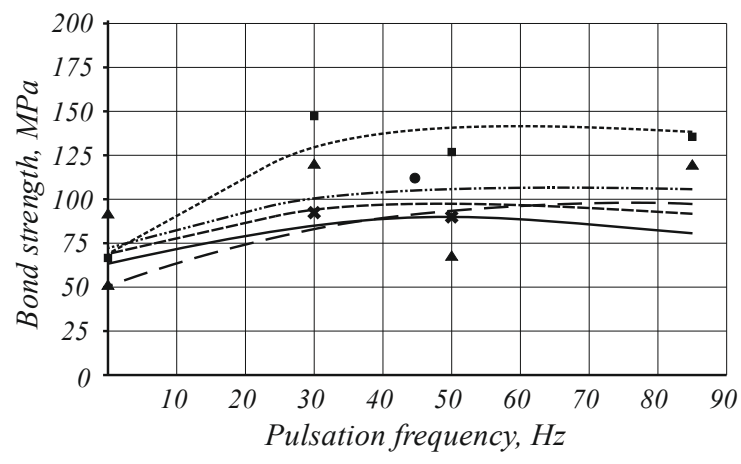

Fig. 5. Adhesion strength of the flux-cored wire coating using a pulsating atomizing air stream

From Fig. 5 it can be seen that when spraying without a pulsating mode of the air-spraying flow, the adhesion strength has low values of the order of $62 \mathrm{MPa}$. As the pulsation is established, an increase in adhesion strength is observed both when using PP-MM-2 and PP-MM-2M with different contents of $\mathrm{KMnO}_{4}$. However, as it is possible to see, when using PP-MM-2, the growth is not as significant as when using PP-MM-2M.

\section{SWOT analysis of research results}

Strengths. The strengths of this study are that the use of a pulsating spray flow in arc spraying significantly affects the quality of the applied coatings and makes it possible to save resources and energy by saving alloying elements, materials and air.

Weaknesses. The weaknesses of this study are related to the fact that the result of the implementation is the need for a strict installation of the pulsator in relation to the entrance to the spray system.

Opportunities. The options proposed in this paper are of a practical nature. Additional possibilities when using the above results in industrial conditions are associated with the possibility of using this process in the case of manual control.

Threats. Additional adjustments are required to develop an automated control system.

\section{Conclusions}

1. An improved system of particle spraying in electric arc metallization is proposed. A relatively simple and inexpensive set of equipment for creating a pulsating jet stream makes it possible to reduce the effect of the amount of oxygen in the air on the burnout of alloying elements in the coating.

2. A systematic analysis of the data obtained in the process of deposition of coatings using a pulsating spraying flow during electric arc metallization with flux-cored wire showed significant changes in the structures of the coating particles. When considering the microstructure of particles of a ferrite or ferrite-pearlite coating, it was found that with an increase in the pulsation frequency, the amount of the carbide phase increases and reaches a maximum at frequencies of $65 \mathrm{~Hz}$. With an increase in frequencies above $85 \mathrm{~Hz}$, a slight decrease in the carbide phase takes place, but quenching structures appear. In general, the microhardness of the coating particles depends on the pulsation frequency of the spray jet and reaches its maximum values at frequencies of $65 \mathrm{~Hz}$. With a further increase in the pulsation frequency, a significant increase in hardness is not observed.

Based on the studies carried out, it has been established that the optimal range of pulsation frequencies of the airspraying jet is $65-85 \mathrm{~Hz}$, which improves the properties of the coating when using PP-MM-2 flux-cored wire.

\section{References}

1. Korzh, V. N., Vorona, T. V., Lopata, A. V. (2014). Kombynyrovannыe metodu ynzheneryy poverkhnosty. Kompleksne zabezpechennia yakosti tekhnolohichnykh protsesiv ta system. Chernihiv: ChNTU, 159-163.

2. Chernovol, M. Y., Vorona, T. V., Lopata, A. V. (2015). Increase in wear resistance of gas-thermal coatings from iron-carbon alloys using electric contact treatment. Tekhnika $v$ silskohospodarskomu vyrobnytstvi, haluzeve mashynobuduvannia, avtomatyzatsiia, 28, 230-236.

3. Chernovol, M. I. et. al. (2015). Strukturno-fazovye prevrascheniya $\mathrm{v}$ gazotermicheskikh stalnykh pokrytiyakh v protsesse ikh napyleniya i posleduyuschie elektrokontaktnye obrabotki. Problema tertya ta znoshuvannya, 2 (67), 99-109.

4. Markov, D., Kelly, D. (2002). Establishment of a new class of wear: adhesion initiated catastrophic wear. International Journal of Applied Mechanics and Engineering, 7 (3), 887-901.

5. Elleuch, K., Fouvry, S. (2005). Experimental and modelling aspects of abrasive wear of a A357 aluminium alloy under gross slip fretting conditions. Wear, 258 (1-4), 40-49. doi: http://doi.org/ 10.1016/j.wear.2004.04.010

6. Belzunce, F. J., Higuera, V., Poveda, S., Carriles, A. (2002). High Temperature Oxidation of HFPD Thermal-Sprayed MCrAlY Coatings in Simulated Gas Turbine Environments. Journal of Thermal Spray Technology, 11 (4), 461-467. doi: http://doi.org/ 10.1361/105996302770348592

7. Fagoaga, I., Barykin, G., De Juan, J., Soroa, T., Vaquero, C., Coddet, C. (Ed.) (1999). The High Frequency Pulse Detonation (HFPD) Spray Process. Proc. United Thermal Spray Conf. ASM International. Düsseldorf, 282-287.

8. Product Data Sheet Sulzer Metco SmartArc Advanced Electric Wire Arc Thermal Spray System. Available at: https://www. oerlikon.com/ecoma/files/DSE-0055.6_SmartArc_EN.pdf? download=true

9. Crawmer, D. E.; Davis, J. R. (Ed.) (2004). Thermal spray process. In Handbook of Thermal Spray Technology. ASM: Novelty, 54-73.

10. Nowak, W., Naumenko, D., Mor, G., Mor, F., Mack, D. E., Vassen, R. et. al. (2014). Effect of processing parameters on MCrAlY bondcoat roughness and lifetime of APS-TBC systems. Surface and Coatings Technology, 260, 82-89. doi: http://doi.org/ 10.1016/j.surfcoat.2014.06.075

11. Curry, N., Markocsan, N., Li, X.-H., Tricoire, A., Dorfman, M. (2010). Next Generation Thermal Barrier Coatings for the Gas Turbine Industry. Journal of Thermal Spray Technology, 20 (1-2), 108-115. doi: http://doi.org/10.1007/s11666-010-9593-x

12. Hardwicke, C. U., Lau, Y.-C. (2013). Advances in Thermal Spray Coatings for Gas Turbines and Energy Generation: A Review. Journal of Thermal Spray Technology, 22 (5), 564-576. doi: http://doi.org/10.1007/s11666-013-9904-0

13. Tejero-Martin, D., Rezvani Rad, M., McDonald, A., Hussain, T. (2019). Beyond Traditional Coatings: A Review on ThermalSprayed Functional and Smart Coatings. Journal of Thermal Spray Technology, 28 (4), 598-644. doi: http://doi.org/10.1007/ s11666-019-00857-1 
14. Meghwal, A., Anupam, A., Murty, B. S., Berndt, C. C., Kottada, R. S., Ang, A. S. M. (2020). Thermal Spray High-Entropy Alloy Coatings: A Review. Journal of Thermal Spray Technology, 29 (5), 857-893. doi: http://doi.org/10.1007/ s11666-020-01047-0

15. Royanov, V. A., Zakharova, I. V., Kryuchkov, N. (2017). Izuchenie vliyaniya konstruktsiy raspylyayuschego ustroystva na kachestvo napylennogo sloya. Universitetskaya nauka-2017. Mariupol: GVUZ «PGTU», 2, 86-87.

16. Royanov, V. A., Zakharova, I. V., Kryuchkov, N. S., Pugachev, E. V. (2019). Snizhenie vozdeřstviya kisloroda na zhidkiı̌ metall elektrodov pri elektrodugovom napylenii pulsiruyuscheř raspylyayuscher̆ strueŭ vozdukha. World science, 5 (45), 13-21. doi: http://doi.org/10.31435/rsglobal_ws/31052019/6508

17. Royanov, V., Zakharova, I., Lavrova, E. (2017). Development of properties of spray flow and nature of pressure distribution in electric arc metalization. Eastern-European Journal of Enterprise Technologies, 6 (5 (90)), 41-49. doi: http://doi.org/ 10.15587/1729-4061.2017.118252

Vyacheslav Royanov, Doctor of Technical Sciences, Professor Department of Automation and Mechanization of Welding Production, State Higher Educational Institution «Priazovskiy State Technical University», Mariupol, Ukraine, ORCID: http://orcid.org/ 0000-0001-5379-9096

Irina Zakharova, PhD, Associate Professor, Department of Automation and Mechanization of Welding Production, State Higher Educational Institution «Priazovskiy State Technical University», Mariupol, Ukraine, ORCID: http://orcid.org/0000-0002-3492-0134

\section{Vladimir Lebedev, \\ Tatiana Chumachenko, Alla Bespalova, Tatiana Nikolaeva, Yevhen Omelchenko}

\section{ANALYSIS OF CUTTING FORCES DURING GRINDING OF TITANIUM ALLOY AND CORROSION-RESISTANT STEEL BY DIAMOND, ELECTROCORUNDUM AND CUBIC BORINE NITRID WHEELS}

The object of research is the process of circular and surface grinding of titanium alloy and corrosion-resistant steel, namely, the cutting forces arising from mechanical processing. One of the most problematic areas in work is the selection of the required grinding modes, material and grinding wheel grain size.

In the course of the experiment, we used samples of VT8 titanium alloy and $12 X 18 \mathrm{~N} 9 \mathrm{~T}$ steel, on which the grinding process was studied with wheels made of various materials (electrocorundum, cubic boron nitride (CBN), diamond). The values of the cutting forces $P_{y}$ and $P_{z}$ were obtained in the latitude of permissible modes, which are most often used in circular and flat grinding, and can reach maximum values, respectively, $P_{y}=27 \mathrm{~N}, P_{z}=15.5 \mathrm{~N}$. The data were obtained at a low wheel speed from electrocorundum, about $15 \mathrm{~m} / \mathrm{s}$ and grain size 8. By reducing the grain size of the wheel, we get the effect of increasing the energy consumption of the grinding process, due to the increase in the values of the cutting forces. If we compare the cutting forces arising from grinding with different wheels, then the following can be noted. Compared to electrocorundum wheels, when using CBN wheels, the cutting forces are reduced by 20-25\%, and when grinding with diamond wheels (despite the high wear of the diamond wheel), the effect of cutting forces is reduced by 25-30\%. This is due to the fact that cutting conditions are the most favorable for diamond and CBN grains, which makes it possible to use more intense cutting conditions.

The results of the study allow predicting the performance of the grinding wheel, reducing the energy consumption of production, and also adjusting the processing mode of the part to obtain the necessary quality indicators of the surface layer and the geometric dimensions of the part.

Keywords: titanium alloy VT8, cutting forces, technical strength, structural strength, reduction of energy consumption for grinding.

How to cite

Lebedev, V., Chumachenko, T., Bespalova, A., Nikolaeva, T., Omelchenko, Y. (2021). Analysis of cutting forces during grinding of titanium alloy and corrosion-resistant steel by diamond, electrocorundum and cubic borine nitrid wheels. Technology Audit and Production Reserves, 3 (1 (59)), $27-33$. doi: http://doi.org/10.15587/2706-5448.2021.235421

\section{Introduction}

Obtaining products from titanium and its alloys is a modern and promising production, especially in the aero- space industry of the world economy. Titanium is a light, heat-resistant, corrosion-resistant construction material. The weight of titanium products is significantly reduced due to its low density $\left(\rho_{t i t}=4.5 \mathrm{~g} / \mathrm{cm}^{3}\right)$. Compared to the 